\title{
SHTN1 Gene
}

National Cancer Institute

\section{Source}

National Cancer Institute. SHTN1 Gene. NCI Thesaurus. Code C122906.

This gene is involved in neuronal polarization. 